for growth, after supplementation with lysine, was I4.8 p. Ioo of a diet containing 85 p. Ioo dry matter, corresponding to $45 \mathrm{~g} / \mathrm{Mcal} \mathrm{DE}$.

A review of the requirement for total balanced protein in growing pigs is presented in the second part of the paper, taking into consideration the whole series of experiments performed on this subject and the recent literature. The following points were examined: significance of total protein requirement, possibility for reducing the total dietary protein after supplementing with the most limiting amino acids, optimum level of balanced protein for growth after supplementing with limiting amino acids. Recommended allowances were given for the supply of balanced proteins and lysine, according to the stage of growth (20-50 et $50-100 \mathrm{~kg}$ live weight), sex (females and castrated males), under conditions of moderately restricted feeding: both in daily amounts and in relation to energy (DE). The potential economy of dietary protein with the improvement of dietary amino acids balance is discussed in connection with the utilization of dietary energy.

\title{
Feed restriction of piglets after weaning : interaction with crude protein supply
}

\author{
B. SEेVE \\ I.N.R.A., Station de Recherches sur l'Élevage des Porcs \\ 78350 Jouy-en-Josas (France)
}

The experiment involved 30 litters including 180 piglets, aged exactly 2 I days and weighing $5.5 \mathrm{~kg}$ on an average (confidence interval, $\pm 0.9 \mathrm{~kg}$ ). The effects of a $25 \mathrm{p}$. Ioo feed restriction compared ad libitum feeding were studied within litters during the two weeks following weaning comparing in each case three dietary protein contents I 5, 20 and $25 \mathrm{p}$. I oo of constant quality (6.5 p. I oo lysine). The diet containing $20 \mathrm{p}$. I oo protein was offered ad libitum to each piglet between 35 and 49 days of age. After a transition period of one week with a second age diet containing I $8 \mathrm{p}$. Ioo protein without skimmilk powder, the growth performance of piglets regrouped in litters were measured until to days of age.

After the first two weeks, the favourable effect of the protein content on growth rate was perfectly linear in piglets fed ad libitum ( 128,160 and $197 \mathrm{~g} / \mathrm{d}$ for $\mathrm{I} 5,20$ and $25 \mathrm{p}$. roo protein, respectively). On the other hand, the protein content did not affect growth rate of restricted piglets (I 22, 122 and $130 \mathrm{~g} / \mathrm{d}$ for $\mathrm{I} 5,20$ and $25 \mathrm{p}$. Ioo protein, respectively). At 70 days of age, piglet weights ranged between 26 and $27.2 \mathrm{~kg}$ according to groups without significant differences. As compared with the group fed ad libitum a diet containing $25 \mathrm{p}$. roo protein, the growth delays observed at 35 days remained minimum or decreased after administration of ad libitum diets containing I 5 and $20 \mathrm{p}$. roo protein or a restricted amount of a diet containing 20 p. Ioo protein. In the latter case, the feed efficiency was maximum between 25 and 56 days of age :6I $6 \mathrm{~g} / \mathrm{kg}$ versus 590, 59I and 6I 3 with the first age diets containing I 5, 20 and 25 p. Ioo proteins offered ad libitum.

Growth delays of piglets receiving after weaning a restricted amount of feeds with extreme protein contents ( 15 and $25 \mathrm{p}$. IOO) persisted (I.3 to I.6 d/piglet) or increased in absolute value. Frequency of diarrhoea as well as piglet losses were not affected either by the protein content or by the feed restriction.

In conclusion, feeding piglets ad libitum with a diet containing $20 \mathrm{p}$. Ioo well balanced proteins during the two weeks following weaning at the age of 3 weeks seems to be a satisfactory solution. 